\title{
Analytical Biochemistry
}

National Cancer Institute

\section{Source}

National Cancer Institute. Analytical Biochemistry. NCI Thesaurus. Code C18632.

Scientific discipline concerned with the development of methods and application of these methods to detect, identify, and quantify biological materials (e.g., proteins, nucleic acids, metabolites). See analytic chemistry. 